\title{
BMJ Open Development and validation of the Health-Friendly Activity Index: an assessment tool to comprehensively measure health-friendly activities of corporations or organisations
}

\author{
Young Ho Yun (D) , ${ }^{1}$ Si Nae Oh, ${ }^{2}$ Jin-Ah Sim, ${ }^{3}$ Sujee Lee, ${ }^{4}$ Eun-Jung Sohn ${ }^{5}$
}

To cite: Yun YH, Oh SN, Sim J$A$, et al. Development and validation of the Health-Friendly Activity Index: an assessment tool to comprehensively measure health-friendly activities of corporations or organisations. BMJ Open 2021;11:e048768. doi:10.1136/ bmjopen-2021-048768

- Prepublication history and additional supplemental material for this paper are available online. To view these files, please visit the journal online (http://dx.doi.org/10.1136/ bmjopen-2021-048768).

Received 06 January 2021 Accepted 11 June 2021

Check for updates

(c) Author(s) (or their employer(s)) 2021. Re-use permitted under CC BY-NC. No commercial re-use. See rights and permissions. Published by BMJ.

For numbered affiliations see end of article.

Correspondence to Professor Young Ho Yun; lawyun08@gmail.com

\section{ABSTRACT}

Objectives We developed the Health-Friendly Activity Index (HFAl) to comprehensively measure the healthfriendly activities of corporations or organisations. We validated the developed tool and reported on its use as an assessment tool to improve consumers' health-related outcomes.

Design This was a cross-sectional study.

Setting Development of the HFAl questionnaire followed a three-phase process: item generation, item construction and validation with field testing. Using relevance and feasibility criteria, we developed a 105-item questionnaire with six domains (Governance and Infrastructure, Needs Assessment, Planning, Implementation, Monitoring and Feedback, and Outcomes).

Participants To assess the sensitivity and validity of the questionnaire, the HFAl and Contribution Assessment Tool for Consumer's Health (CATCH) were administered to 302 participants (151 employers and 151 employees) from 151 Korean companies.

Primary outcome measures The CATCH measured the contribution of each company to the physical, mental, social and spiritual health of its consumers. To estimate the reliability and validity of all six HFAl domains and their respective scales, Cronbach's $\alpha$ coefficients and correlation coefficients were used.

Results Each domain and scale of the HFAl exhibited a Cronbach's $\alpha$ coefficient between 0.80 and 0.98 for the employers and employees. The overall HFAl and its six domains correlated significantly and positively with all health outcomes such as physical, mental, social and spiritual status scores evaluated using the $\mathrm{CATCH}$ (Spearman's correlation range: $0.37-0.68$ ).

Conclusion The HFAl, a unique assessment tool with acceptable psychometric properties, can help corporate managers assess their health-friendly activities.

\section{INTRODUCTION}

The world is facing increasing health problems, and health has become an important global issue addressed in the United Nations' Sustainable Development Goals. ${ }^{1}$ People have begun to recognise that although
Strengths and limitations of this study

- This study validated a newly developed HealthFriendly Activity Index with representative employers and employees of corporations or organisations.

- Further validation studies are necessary for generalisation of the results to other countries.

- There were minimal differences between each employer's and employee's evaluation scores of their company's health-friendly activities; however, these evaluations should be validated using objective document reviews, site visits or employee surveys.

health is mainly the responsibility of the government in most countries, companies can play an important role in building a health ecosystem. ${ }^{2}$ In fact, companies affect consumers' health and wellness both positively and negatively, directly through their products and services; therefore, they have the opportunity to address the non-medical, social, and environmental determinants of health, and reframe consumers' health and wellness. $^{2} 3$ Stakeholders, including consumers, employees, investors, community organisations and government officials, understand that companies are facing increasing pressure to improve consumer health outcomes. ${ }^{2} 3$ However, many companies settle for achieving 'less bad' rather than 'good' customer health and wellness outcomes. $^{2-4}$

We propose here the concept of 'healthfriendly management', which refers to the promotion of various healthy components or the avoidance of harmful components, which affect physical, mental, social or spiritual health. 'Health-friendly management' is based mainly on the concept of creating shared values $(\mathrm{CSVs}){ }^{3}$ In early 2018, we surveyed 1200 individuals from the 
general Korean population; results suggested that most consumers perceive health-friendly labels as important when purchasing products or services, and are willing to pay extra for health-friendly products or services. ${ }^{35-8}$ Emphasising health-friendly labels accredited by reputable organisations for products or services would help to build brand reliability and awareness among consumers. ${ }^{89}$

For workplace health and wellness programmes to improve employee health as a part of corporate social responsibility (CSR), the Centers for Disease Control and Prevention (CDC) developed the Worksite Health Score Card, a self-assessment survey instrument. ${ }^{10}$ Additionally, we developed the Worksite Health Index (WHI) to assess comprehensive worksite health programmes. ${ }^{11}$ To our knowledge, however, there is currently no assessment tool to measure the health-friendly activities of corporations or organisations, and to improve consumers' healthrelated outcomes.

In the present study, we developed and validated a new instrument to measure the health-friendly activities of corporations or organisations-the Health-Friendly Activity Index (HFAI) - to measure the health-friendly activities of corporations or organisations using a representative sample of employers and employees of organisations. We designed this tool to assist managers in addressing the challenges of producing high-quality, health-friendly products and services, and implementing science-based and practice-based strategies that improve customers' health and wellness. The end users of this tool include companies ranging from food manufacturers to wholesale and retail traders that deal with 'health-friendly' products or services. About $90 \%$ of companies agree that they can help improve the health of their consumers, ${ }^{2}$ and managers tasked with contributing to consumer health using high-quality products and services, through initiatives that go beyond mere profit, would be benefited as target users of this HFAI. ${ }^{349}$

\section{METHODS}

Development and validation of the HFAI was carried out in three phases following the assessment tool development process: (1) item generation; (2) construction of domains, scales and items; and (3) validation with field testing. Statistical analyses for reliability and validity were conducted.

\section{Phase I: item generation}

For phase I, we organised lists of indicators relevant to a company's health-friendly activities, as well as to CSR and CSV sectors that are associated with social contribution. We developed lists of indicators in tandem with our development of the WHI. ${ }^{11}$ We first reviewed more than 20 published indexes, such as the FSG Measuring Shared Value, ${ }^{12}$ the B Corporation Global Impact Investing Rating System Index, ${ }^{13}{ }^{14}$ the Dow Jones Sustainability Index, ${ }^{15}$ the Health Impact Assessment, ${ }^{16}$ the Nestlé CSV Report, ${ }^{17}$ the British Government's CSR Index, ${ }^{18}{ }^{19} \mathrm{CSV},{ }^{20}{ }^{21}$ Porter
\& Kramer Moore, ${ }^{19}$ the CDC Worksite Health Scorecard $^{10}{ }^{22}$ and CSR. ${ }^{2}{ }^{4}$ To integrate health-friendliness into the value chain and culture of corporates with the consensus that companies should try to contribute to consumer and public health, stakeholders including managers, employees, investors, consumers and community organisations were recruited for the interviews. We contacted a group of 28 experts (four family medicine, four chief executive officers (CEOs), one consulting firm director, three company executives, two CSV experts, six business administration professors, three physical education experts, four occupational health experts and one Korea Occupational Health Agency assistant chief). Among them, 24 professionals participated in both the semistructured interviews and Delphi process. We generated new assessment items for health-friendly activities to determine the companies' contribution to consumers' health. We summarised field experiences and insights, and used them to construct the framework of the HFAI.

To generate the domains, other than field experiences and insights from semistructured interviews, we maintained the domains from the WHI framework that was initially designed together with WHI and validated earlier. ${ }^{11}$ In addition to the WHI framework, we also applied the concept of life cycle assessment (LCA), ${ }^{23}$ a method to assess environmental impacts associated with all stages of a product's life, commercial product, process or service. Based on the LCA and WHI framework, we incorporated experts' opinions and feedback from semistructured interviews to generate HFAI domains and assess the health impacts associated with all stages of a product's or service's life on the consumer. The six domains and their scales were chosen from the framework of the WHI, ${ }^{11}$ and indexes and semistructured interviews from previous studies. We then generated six domains for a total of 125 items reflecting key issues. The six domains are: (1) Governance and Infrastructure, (2) Needs Assessment, (3) Planning, (4) Implementation, (5) Monitoring and Feedback, and (6) Outcomes. The Governance and Infrastructure domain includes three scales: Philosophy, Policy and Infrastructure of Company. The Needs Assessment domain includes two scales: Needs Assessment and Actual Condition Investigation. The Planning domain includes three scales: Planning, Budget, and Participation and Cooperation. The Implementation domain includes eight scales: Research and Development, Purchase of Raw Material, Product Production/Service Provision, Promotion/Marketing, Packing/Distribution, Sales/Disposal/ Post-marketing Management, Information Disclosure and Creating Health Value for Products/Services. The Monitoring and Feedback domain includes three scales: Evaluation System, Monitoring and Reflection on Postplan. Finally, the Outcomes domain includes no scales.

\section{Phase II: original item construction}

The list was created using the Delphi method originally developed in 1967 by the RAND Corporation. ${ }^{24}$ A group of 28 experts anonymously checked the feasibility and 
reliability of each item based on a 5-point Likert scale, and subsequently provided feedback. This process was repeated twice. Items remained on the list if four criteria were met: (1) relevance mean score $\geq 3.0$, (2) feasibility mean score $\geq 2.5$, (3) prevalence ratio of less than relevance mean score $3 \leq 25 \%$, and (4) prevalence ratio of less than feasibility mean score $3 \leq 25 \%$. Items that did not meet these four criteria were deleted. Using this method, we deleted 20 items, and the first version of the HFAI was reduced to 105 items on the questionnaire. To rate the assessment tool for evaluation, we used a yes/ no scale.

\section{Phase III: validation with field testing}

To test reliability and validity, both employers and employees were selected independently as participants from 1500 eligible companies between July and August 2020. The inclusion criteria for employers were as follows: (1) are in charge of human resources, general affairs, management, finance or labour, (2) are the CEO or representative of the employer, and (3) voluntarily agreed to participate in the survey. The inclusion criteria for employees were as follows: (1) are in charge of development, planning or marketing, (2) are representatives of employees, and (3) voluntarily agreed to participate in the survey. There were no exclusion criteria. Two web survey systems, Computer Assisted Web Interview and Computer Assisted Mobile Interview that enable online responses by sending survey requests to participants' email accounts and phone numbers, were applied. The companies were selected with consideration of the size, industry and business type for obtaining a representative national sample; this sample was pooled for the web survey by the Hankook Research Co (Seoul, Korea) since 2015. A total of 151 companies (10\% response rate) responded to the self-reported questionnaire.

To estimate the reliability of all six HFAI domains and their scales, Cronbach's $\alpha$ coefficients were used. To assess the concurrent validity of the HFAI domains, the enrolled participants were asked to complete the Contribution Assessment Tool for Consumer's Health (CATCH). ${ }^{3}$ The CATCH consists of 20 items $(0=$ not at all helpful, $10=$ very helpful) that measure the contribution of each participant's company to the physical, mental, social and spiritual health of its consumers. We also collected information about worksite demographics, such as number of employees, business type and industry. The survey was conducted online.

All calculated $\mathrm{p}$ values were two-sided with the significance level set at $\mathrm{p}<0.05$. SAS statistical package V.9.3 (SAS Institute) and R V.3.5.1 were used for all analyses.

\section{Patient and public involvement}

Neither patients nor the public were involved in the design, conduct, reporting or dissemination of our research.

\begin{tabular}{lc}
$\begin{array}{l}\text { Table } 1 \text { The demographic characteristics of } 151 \text { participant } \\
\text { companies }\end{array}$ & No (\%) \\
\hline Characteristics & \\
\hline No of employees & $35(23.2)$ \\
\hline $10-299$ & $40(26.5)$ \\
\hline $300-999$ & $76(50.3)$ \\
$\geq 1000$ & \\
\hline Business type & $116(76.8)$ \\
\hline Profit & $24(15.9)$ \\
\hline Non-profit (public) & $11(7.3)$ \\
\hline Non-profit (private) & \\
\hline Industry sector & $44(29.1)$ \\
\hline Manufacturing & $19(12.6)$ \\
\hline Professional, scientific and technical & $14(9.3)$ \\
\hline Human health and social work & $12(8.0)$ \\
\hline Financial and insurance & $14(9.3)$ \\
\hline Construction & $13(8.6)$ \\
\hline Transportation and storage & $7(4.6)$ \\
\hline Administration & $7(4.6)$ \\
\hline Wholesale and retail trade & $5(3.3)$ \\
\hline Information and communication technologies & $5(3.3)$ \\
\hline Mining and quarrying, and oil and gas & $2(1.3)$ \\
\hline extraction & $2(1.3)$ \\
\hline Waste management and materials recovery & $1(0.7)$ \\
\hline Accommodation and food service & $1(0.7)$ \\
\hline Art, entertainment and recreation & $5(3.3)$ \\
\hline Education service & \\
\hline Others & \\
\hline & \\
\hline
\end{tabular}

\section{RESULTS}

A total of 125 items reflecting key issues were generated for six domains in phase I. In phase II, 20 items that did not meet these four criteria were deleted. The final HFAI consisted of 5 domains, 19 subscales and 105 items.

\section{Sample characteristics}

One hundred fifty-one companies of varying sizes, business types and industry sectors were recruited (151 employers and 151 employees) from the Republic of Korea. Table 1 summarises the demographics of the study participants' companies.

\section{Reliability}

We assessed the tool's reliability by determining the Cronbach's $\alpha$ coefficient of the HFAI scores for the employers and employees. All HFAI domains and scales exhibited a Cronbach's $\alpha$ coefficient between 0.802 and 0.979 for the employers and employees, suggesting acceptable reliability with good internal consistency (table 2). 
Table 2 Domain, scale organisation and reliability of HFAl scores

\begin{tabular}{|c|c|c|c|c|c|}
\hline Domain & Number of questions & $\begin{array}{l}\text { Total } \\
\text { Mean (SD) }\end{array}$ & $\begin{array}{l}\text { Employer } \\
\text { Mean (SD) }\end{array}$ & $\begin{array}{l}\text { Employee } \\
\text { Mean (SD) }\end{array}$ & Cronbach's $\alpha$ \\
\hline Governance and Infrastructure & 24 & $54.73(37.29)$ & $54.30(36.72)$ & $55.16(37.98)$ & 0.966 \\
\hline Corporate philosophy & 13 & $57.54(38.00)$ & $57.26(37.90)$ & $57.82(38.22)$ & 0.944 \\
\hline Policy & 3 & $51.32(43.60)$ & $51.21(43.68)$ & $51.43(43.67)$ & 0.842 \\
\hline Infrastructure & 8 & $51.45(40.44)$ & $50.66(40.07)$ & $52.24(40.93)$ & 0.925 \\
\hline Needs Assessment & 6 & $48.12(39.26)$ & 49.01 (38.88) & $47.24(39.74)$ & 0.879 \\
\hline Need assessment & 1 & $48.68(50.07)$ & $49.01(50.16)$ & $48.34(50.14)$ & NA \\
\hline Status assessment & 5 & $48.01(39.98)$ & $49.01(39.78)$ & $47.02(40.28)$ & 0.906 \\
\hline Planning & 14 & 47.89 (39.62) & $48.53(39.00)$ & $47.26(40.34)$ & 0.954 \\
\hline Planning & 1 & $49.01(50.07)$ & $49.67(50.17)$ & $48.34(50.14)$ & NA \\
\hline Budget & 6 & $48.01(41.25)$ & $48.01(40.14)$ & $48.01(42.47)$ & 0.912 \\
\hline Participation and corporation & 7 & $47.63(40.38)$ & $48.82(41.22)$ & 46.45 (39.63) & 0.876 \\
\hline Implementation & 40 & $50.36(37.02)$ & $51.29(35.47)$ & $49.42(38.61)$ & 0.979 \\
\hline R\&D planning & 4 & $49.42(42.67)$ & $50.17(42.77)$ & $48.68(42.70)$ & 0.876 \\
\hline Purchase of raw materials & 4 & $47.19(43.95)$ & $47.85(44.06)$ & $46.52(43.97)$ & 0.902 \\
\hline Product production & 10 & $57.45(38.33)$ & $59.14(37.38)$ & $55.76(39.32)$ & 0.929 \\
\hline $\begin{array}{l}\text { Advertisement/ } \\
\text { marketing }\end{array}$ & 4 & $43.87(41.61)$ & $44.37(41.05)$ & $43.38(42.30)$ & 0.860 \\
\hline Package/logistics & 3 & $48.12(42.21)$ & $48.57(41.76)$ & $47.68(42.78)$ & 0.802 \\
\hline $\begin{array}{l}\text { Sales/disposal/post- } \\
\text { management }\end{array}$ & 4 & $51.24(40.71)$ & $51.82(39.70)$ & $50.66(41.83)$ & 0.835 \\
\hline Disclosure & 7 & $46.64(40.68)$ & 47.78 (39.76) & $45.51(41.68)$ & 0.917 \\
\hline Creating health value & 4 & $50.50(43.70)$ & $50.83(43.25)$ & $50.17(44.30)$ & 0.897 \\
\hline Monitoring and Feedback & 12 & $47.21(41.47)$ & 47.52 (40.69) & $46.91(42.37)$ & 0.959 \\
\hline Evaluation system & 6 & $45.75(42.31)$ & $45.47(41.18)$ & $46.03(43.53)$ & 0.922 \\
\hline Monitoring & 2 & $47.19(47.01)$ & $46.69(46.79)$ & $47.68(47.38)$ & 0.869 \\
\hline Backward planning & 4 & $49.42(44.48)$ & 50.99 (44.34) & 47.85 (44.72) & 0.913 \\
\hline Outcome & 9 & $60.34(44.17)$ & $61.81(44.00)$ & $58.87(44.48)$ & 0.936 \\
\hline Total & 105 & $51.40(36.67)$ & $51.95(35.25)$ & $50.84(38.15)$ & 0.991 \\
\hline
\end{tabular}

HFAI, Health-Friendly Activity Index; NA, not applicable; R\&D, research and development.

\section{Validity}

The overall HFAI scores correlated significantly positively with all the health outcomes, such as physical, mental, social and spiritual status scores, evaluated using the CATCH. The Spearman's correlation ( $r$ ) range was significant at $0.37-0.68$ (table 3 ).

\section{DISCUSSION}

This study developed and validated the HFAI as an assessment tool to measure the health-friendly activities of corporations and organisations and thus improve consumers' health-related outcomes. Companies with higher HFAI scores showed significantly better health outcomes as evaluated by the participants. Companies with higher total HFAI scores, which include higher scores in domains such as Governance and Infrastructure, Needs Assessment, Planning, Implementation, Monitoring and Feedback, and
Outcomes, showed significantly better self-rated contributions to consumer's health. Managers can use the HFAI to assess their current activities related to consumers' health and wellness, identify policy gaps and prioritise high-impact interventions for critical health topics. ${ }^{10}$ Companies may also find this tool useful for boosting consumer motivation and strengthening consumer loyalty. ${ }^{11}$

Perhaps the most interesting finding of this study is that the HFAI appears to be sensitive to the participants' ratings of how much their corporations contribute to consumer health. Significant associations were found between the HFAI scores and the ratings of the companies' contributions to consumers' physical, psychological, social and spiritual health. These findings are noteworthy because they suggest the usefulness and impact of the HFAI on companies' health-friendly activities. To maintain good relationships with consumers, it is particularly crucial for managers 
Table 3 Correlation between HFAI score and scores of contributions to health status of the general population by CATCH

CATCH

\begin{tabular}{|c|c|c|c|c|c|c|c|c|c|}
\hline \multirow[b]{3}{*}{ Domain } & & & \multicolumn{7}{|c|}{ Health status } \\
\hline & & \multicolumn{2}{|c|}{ Physical } & \multicolumn{2}{|c|}{ Mental } & \multicolumn{2}{|c|}{ Social } & \multicolumn{2}{|c|}{ Spiritual } \\
\hline & & $r$ & $P$ value & $r$ & $P$ value & $r$ & $P$ value & $r$ & $P$ value \\
\hline \multirow[t]{3}{*}{ Governance/Infrastructure } & Total & 0.50 & $<0.001$ & 0.48 & $<0.001$ & 0.51 & $<0.001$ & 0.57 & $<0.001$ \\
\hline & Employer & 0.37 & $<0.001$ & 0.39 & $<0.001$ & 0.44 & $<0.001$ & 0.51 & $<0.001$ \\
\hline & Employee & 0.61 & $<0.001$ & 0.56 & $<0.001$ & 0.57 & $<0.001$ & 0.63 & $<0.001$ \\
\hline \multirow[t]{3}{*}{ Needs Assessment } & Total & 0.49 & $<0.001$ & 0.44 & $<0.001$ & 0.47 & $<0.001$ & 0.52 & $<0.001$ \\
\hline & Employer & 0.37 & $<0.001$ & 0.37 & $<0.001$ & 0.40 & $<0.001$ & 0.47 & $<0.001$ \\
\hline & Employee & 0.60 & $<0.001$ & 0.49 & $<0.001$ & 0.53 & $<0.001$ & 0.57 & $<0.001$ \\
\hline \multirow[t]{3}{*}{ Planning } & Total & 0.57 & $<0.001$ & 0.52 & $<0.001$ & 0.57 & $<0.001$ & 0.60 & $<0.001$ \\
\hline & Employer & 0.48 & $<0.001$ & 0.49 & $<0.001$ & 0.57 & $<0.001$ & 0.58 & $<0.001$ \\
\hline & Employee & 0.64 & $<0.001$ & 0.54 & $<0.001$ & 0.57 & $<0.001$ & 0.63 & $<0.001$ \\
\hline \multirow[t]{3}{*}{ Implementation } & Total & 0.61 & $<0.001$ & 0.55 & $<0.001$ & 0.59 & $<0.001$ & 0.62 & $<0.001$ \\
\hline & Employer & 0.54 & $<0.001$ & 0.55 & $<0.001$ & 0.59 & $<0.001$ & 0.60 & $<0.001$ \\
\hline & Employee & 0.67 & $<0.001$ & 0.55 & $<0.001$ & 0.60 & $<0.001$ & 0.63 & $<0.001$ \\
\hline \multirow[t]{3}{*}{ Monitoring/Feedback } & Total & 0.58 & $<0.001$ & 0.53 & $<0.001$ & 0.57 & $<0.001$ & 0.60 & $<0.001$ \\
\hline & Employer & 0.48 & $<0.001$ & 0.50 & $<0.001$ & 0.57 & $<0.001$ & 0.57 & $<0.001$ \\
\hline & Employee & 0.66 & $<0.001$ & 0.56 & $<0.001$ & 0.58 & $<0.001$ & 0.63 & $<0.001$ \\
\hline \multirow[t]{3}{*}{ Outcome } & Total & 0.60 & $<0.001$ & 0.57 & $<0.001$ & 0.62 & $<0.001$ & 0.65 & $<0.001$ \\
\hline & Employer & 0.52 & $<0.001$ & 0.53 & $<0.001$ & 0.61 & $<0.001$ & 0.62 & $<0.001$ \\
\hline & Employee & 0.68 & $<0.001$ & 0.60 & $<0.001$ & 0.63 & $<0.001$ & 0.67 & $<0.001$ \\
\hline \multirow[t]{3}{*}{ Total } & Total & 0.60 & $<0.001$ & 0.55 & $<0.001$ & 0.60 & $<0.001$ & 0.63 & $<0.001$ \\
\hline & Employer & 0.51 & $<0.001$ & 0.53 & $<0.001$ & 0.58 & $<0.001$ & 0.61 & $<0.001$ \\
\hline & Employee & 0.67 & $<0.001$ & 0.57 & $<0.001$ & 0.61 & $<0.001$ & 0.66 & $<0.001$ \\
\hline
\end{tabular}

CATCH, Contribution Assessment Tool for Consumer's Health; HFAI, Health-Friendly Activity Index.

to focus on the holistic health needs of consumers, as our earlier study suggested. ${ }^{3}$ In the spirit of total quality management, the HFAI also includes a comprehensive evaluation framework to inform managers and consumers about the companies' health-friendly activities. ${ }^{25}$

Our research further suggests that companies should broaden their scope to address not just the health of their employees, ${ }^{11}$ but also the health of other key populations they influence. Nine out of 10 companies agree that they could help strengthen consumers' health, and have a greater impact on health and wellness across the value chain than they do currently. ${ }^{2}$ To integrate healthfriendliness into their value chain and culture, companies can use our assessment tool to discover key performance indicators in a full and transparent manner, motivating employees to strengthen their customers' health through daily actions. ${ }^{2}$ The HFAI could enable companies' key stakeholders to understand how companies can specifically improve the health of their consumers and make informed decisions about future investments. ${ }^{232126}$ All of these factors might contribute to improving managers' competitiveness in the marketplace. ${ }^{3911}$
Companies can use the HFAI to comprehensively understand their current health-friendly activities related to consumers' health and wellness, ranging from aspects of governance and infrastructure to outcome measurement. HFAI can also be used to implement key practices, strategies, and interventions for consumers' health and wellness. Companies may evaluate their own health-friendly activities, but this evaluation may also be conducted by experts or specialised institutions through document reviews and in-depth visits.

However, the HFAI has several limitations. First, in the development of the HFAI, the definition of health-friendly activities of corporations was unclear. ${ }^{27}$ Further studies could improve the conception and implementation of the tool. Second, as this study was conducted only in Korea, further validation studies are necessary for generalisation to other countries. Third, respondents might have difficulty in determining whether a health-friendly activity counts for a 'YES' response in each HFAI item. ${ }^{11}$ Fourth, although the 105item HFAI has the psychometric properties of reliability and validity, some scores of the HFAI, such as Governance/Infrastructure and Needs Assessment, showed weak correlations 
( $\mathrm{r}$ less than 0.4 ) with physical and mental health outcomes among employers. Finally, there were minimal differences in scores between each employer's and employee's evaluation of their company's health-friendly activity (table 2), and contribution to consumers' health and wellness (online supplemental appendix 1); however, their scores were not significantly correlated. These findings suggest that healthfriendly activities of corporations need to be further validated using objective document reviews, site visits or employee surveys.

In conclusion, we believe that the HFAI, a unique assessment tool with acceptable psychometric properties, can help managers assess and modify their health-friendly activities. In particular, this tool can help managers improve marketing strategies and product development, as concern and interest in health is increasing globally, and the credibility of their health effects might affect their competitiveness and consumers' purchasing decisions. ${ }^{28-30}$

\section{Author affiliations}

${ }^{1}$ Department of Family Medicine, Seoul National University College of Medicine, Seoul, South Korea

${ }^{2}$ Department of Family Medicine, Seoul National University Hospital, Jongno-gu, South Korea

${ }^{3}$ School of Al Convergence, Hallym University, Chuncheon, South Korea

${ }^{4}$ University of Wisconsin Madison, Madison, Wisconsin, USA

${ }^{5}$ Family Science and Social Work, Miami University, Oxford, Ohio, USA

Acknowledgements We would like to thank Editage (www.editage.co.kr) for English language editing.

Contributors YHY participated in the study design, provided financial support and study materials, collected and assembled the data, interpreted the analyses, participated in the sequence alignment, drafted the manuscript and finally approved the paper. SNO participated in the study design and coordination, collected study materials, conducted data analyses and wrote the manuscript. JAS participated in the study design, collected study materials and wrote the manuscript. SL participated in the study design, collected study materials and wrote the manuscript. E-JS participated in the study design, collected study materials and wrote the manuscript.

Funding This study was supported by grants from the Seoul National University, Seoul, Korea (grant numbers 800-20170241 and 800-20190030).

Competing interests None declared.

Patient consent for publication Not required.

Ethics approval All the procedures performed in this study involving human participants were in accordance with the ethical standards of the Institutional Research Committee and with the 1964 Helsinki Declaration and its later amendments or comparable ethical standards. Our study on developing and validating the HFAl was reviewed and approved by the Institutional Review Board (IRB) of the Seoul National University Hospital (SNUH; IRB No. 1904-082-1026 and 2011-150-1175) as an IRB review exemption study. As we collected survey questionnaire data from unspecified companies, did not collect personally identifiable or sensitive information, did not manipulate human subjects or the environment, and did not involve subjects in a vulnerable environment, this study was exempted from ethics approval by our ethics committee.

Provenance and peer review Not commissioned; externally peer reviewed.

Data availability statement Data are available upon reasonable request. Extra data can be accessed via the Dryad data repository at http://datadryad.org/ with the doi: $10.5061 /$ dryad.h44j0zpkb.

Supplemental material This content has been supplied by the author(s). It has not been vetted by BMJ Publishing Group Limited (BMJ) and may not have been peer-reviewed. Any opinions or recommendations discussed are solely those of the author(s) and are not endorsed by BMJ. BMJ disclaims all liability and responsibility arising from any reliance placed on the content. Where the content includes any translated material, BMJ does not warrant the accuracy and reliability of the translations (including but not limited to local regulations, clinical guidelines, terminology, drug names and drug dosages), and is not responsible for any error and/or omissions arising from translation and adaptation or otherwise.

Open access This is an open access article distributed in accordance with the Creative Commons Attribution Non Commercial (CC BY-NC 4.0) license, which permits others to distribute, remix, adapt, build upon this work non-commercially, and license their derivative works on different terms, provided the original work is properly cited, appropriate credit is given, any changes made indicated, and the use is non-commercial. See: http://creativecommons.org/licenses/by-nc/4.0/.

ORCID iD

Young Ho Yun http://orcid.org/0000-0002-2740-7279

\section{REFERENCES}

1 United Nations. The sustainable development goals, 2020. Available: https://www.un.org/sustainabledevelopment/sustainabledevelopment-goals/

2 Business for Social Responsibility. A new CSR frontier: business and population health; 2013.

3 Yun YH, Sim JA, Kim Y, et al. Consumers' consciousness of health-friendly products and services and its association with sociodemographic characteristics and health status: a crosssectional survey of the South Korean population. BMJ Open 2020;10:e035591.

4 Visser W. The age of responsibility: Csr 2.0 and the new DNA of business. Journal of Business Systems, Governance and Ethics 2010;5:7.

5 Kabir A, Jahan K. Factors of consumers perceptions \& purchase intentions towards green products. Journal of Business Studies 2014;35:239-56.

6 Jindabot T. The Relationship of Thai Consumers' Health Consciousness and Perceived Value. Global Journal of Emerging Trends in e-Business, Marketing and Consumer Psychology 2015;1:259-68.

7 OZ Y, OZBUK MY. Consumer clusters based on health and price consciousness. Proceedings of the International Academic Research Conference on Marketing \& Tourism, 2016.

8 Singh S, Singh D, Thakur KS. Consumer's attitude and purchase intention towards green products in the FMCG sector. Pacific Business Review International 2014;7:27-46.

9 Kong W, Harun A, Sulong R. The influence of consumers perception of green products on green purchase intention. International Journal of Asian Social Science 2014;4:924-39.

10 Roemer EC, Kent KB, Samoly DK, et al. Reliability and validity testing of the CDC worksite health ScoreCard: an assessment tool to help employers prevent heart disease, stroke, and related health conditions. J Occup Environ Med 2013;55:520-6.

11 Yun YH, Sim JA, Lim YJ, et al. Development and validity testing of the worksite health index: an assessment tool to help and improve Korean employees' health-related outcome. $J$ Occup Environ Med 2016;58:623-30.

12 Michael Porter E E, Pfitzer M, Patscheke S. Measuring shared value: how to unlock value by linking social and business results. Austin, Texas: FSG, 2013.

13 Global Impact Investing Rating System (GIIRS): impact investing, challenges and opportunities to scale: B Corporation 2011.

14 Honeyman R, Jana T. The B Corp Handbook: how you can use business as a force for good. San Francisco: Berrett-Koehler Publishers, 2019.

15 RobecoSAM. Dow Jones sustainability index 2014 review results. New York RobecoSAM; 2014.

16 . Health impact assessment: concepts and guidelines for the Americas. Washington, D.C. Pan American Health Organization; 2013.

17 Nestlé SA. Nestlé in society: creating shared value full report. Zurich Nestles; 2014.

18 Bichta C. Corporate social responsibility: a role in government policy and regulation? Bath The University of Bath; 2003.

19 Moon J20-2004. Government as a driver of corporate social responsibility: the UK in comparative perspective. Nottingham Nottingham University; 2004.

20 Porter ME, Kramer M. Creating shared value, 2011.

21 Heifer International. Corporate Social Responsibility and Creating Shared Value: What's the Difference? 2014.

22 Matson-Koffman DM. The CDC worksite health scorecard; an assessment tool for employers to prevent heart disease, stroke, 
\& related health conditions. Centers for Disease Control and Prevention, 2014.

23 Klöpffer W, Grahl B. Life cycle assessment ( $L C A)$ : a guide to best practice. Hoboken: John Wiley \& Sons, 2014.

24 Turoff M. The design of a policy Delphi. Technol Forecast Soc Change 1970;2:149-71.

25 Grossmeier J, Terry PE, Cipriotti A, et al. Best practices in evaluating worksite health promotion programs. Am J Health Promot 2010;24:TAHP-1-TAHP-11.

26 Kottke TE, Pronk N, Zinkel AR, et al. Philanthropy and beyond: creating shared value to promote well-being for individuals in their communities. Perm J 2017;21:16-188.
27 Dahlsrud A. How corporate social responsibility is defined: an analysis of 37 definitions. Corporate Social Responsibility and Environmental Management 2008;15:1-13.

28 Plasek B, Temesi Ágoston. The credibility of the effects of functional food products and consumers' willingness to purchase/willingness to pay- review. Appetite 2019;143:104398.

29 Cuesta-Valiño P, Rodríguez PG, Núñez-Barriopedro E. Perception of advertisements for healthy food on social media: effect of attitude on consumers' response. Int J Environ Res Public Health 2020;17:6463.

30 Udomkun P, llukor J, Mockshell J, et al. What are the key factors influencing consumers' preference and willingness to pay for meat products in eastern DRC? Food Sci Nutr 2018;6:2321-36. 